\title{
Retraction Note: The diagnostic value of combined dynamic contrast-enhanced MRI (DCE-MRI) and diffusion-weighted imaging (DWI) in characterization of parotid gland tumors
}

\author{
Mohamed Ali EL-Adalany, Amany Ezzat Mohamed Mousa and Dina EL-Metwally*
}

Retraction Note: Egyptian Journal of Radiology and Nuclear Medicine (2020) 51:126.

https://doi.org/10.1186/s43055-020-00237-8

The Editor-in-Chief has retracted this article [1] because the following images presented as part of the case descriptions are replicated from [2] and [3] where they are part of case descriptions of different patients:

Image $\mathrm{E}$ in Figure 1

Image $\mathrm{F}$ in Figure 2

Image $\mathrm{E}$ in Figure 3

Mohamed Ali EL-Adalany and Dina EL-Metwally agree with this retraction. Amany Ezzat Mohamed Mousa has not responded to any correspondence from the Publisher about this retraction.

Published online: 08 September 2020 3. Nehal Tharwat Mohammed El-Sayed. Role of multidetector CT and MRI in
evaluation of parotid gland tumors. MD Thesis defended at the Department
of Radiodiagnosis, Faculty of Medicine, Mansoura University, 2016

The original article can be found online at https://doi.org/10.1186/s43055020-00237-8.

* Correspondence: elmetwallydina@gmail.com

Department of Diagnostic Radiology, Faculty of Medicine, Mansoura

University, Mansoura, Egypt

Springer Open (c) The Author(s). 2020 Open Access This article is licensed under a Creative Commons Attribution 4.0 International License, which permits use, sharing, adaptation, distribution and reproduction in any medium or format, as long as you give appropriate credit to the original author(s) and the source, provide a link to the Creative Commons licence, and indicate if changes were made. The images or other third party material in this article are included in the article's Creative Commons licence, unless indicated otherwise in a credit line to the material. If material is not included in the article's Creative Commons licence and your intended use is not permitted by statutory regulation or exceeds the permitted use, you will need to obtain permission directly from the copyright holder. To view a copy of this licence, visit http://creativecommons.org/licenses/by/4.0/. 